\title{
TRANSAÇÕES DESEJADAS: ANÚNCIOS DE VENDAS DE CATIVOS E OS DIVERSOS SENTIDOS DESSAS NEGOCIAÇÕES, BRASIL, 1850-1880
}

\author{
DESIRED TRANSACTIONS: SLAVES SALES ADVERTISEMENT AND \\ THE DIFFERENT MEANINGS OF THESE NEGOTIATIONS, BRAZIL, \\ 1850-1880
}

\author{
Rafael da Cunha Scheffer ${ }^{1}$
}

RESUMO: O presente artigo discute os diferentes significados do momento da venda de um escravo e os diversos conflitos e tensões que o cercavam. São usados anúncios de venda de cativos em jornais brasileiros na segunda metade do século XIX, buscando informações que nos ajudem a entender as motivações dessas transações. Os diferentes anúncios nos possibilitam perceber esse momento de tensão também como uma válvula de escape para conflitos cotidianos, que resultavam não só da vontade senhorial como também da agência escrava. Ao longo do artigo, procuramos explorar como essas transações devem ser pensadas como uma possibilidade de mudança dentro da ordem, acionado por senhores bem como pelos próprios escravizados, constituindo situações mais complexas do que simples relações comerciais.

PALAVRAS-CHAVE: escravidão; comércio de escravos; anúncios.

ABSTRACT: This article discusses the different meanings of the slave selling moment and the various conflicts and tensions that surround it. We use advertisements for the slave's sales in Brazilian newspapers in the second half of the 19th century to support the analysis, seeking information to help us understand the motivations of these transactions. The different advertisements allow us to perceive this moment of tension as an escape valve for everyday conflicts, which resulted not only from the master's will but also from the slave

\footnotetext{
* Este artigo é resultado de pesquisas realizadas no Mestrado, desenvolvido na Universidade Federal de Santa Catarina - UFSC, com financiamento do CNPq, e do projeto de pesquisa "O comércio de escravos no Ceará, 1850-1888: atuação de negociantes, direções de comércio e perfil de negociados", que também contou com financiamento do CNPq.

${ }^{1}$ Professor Doutor - Instituto de Humanidades - Universidade da Integração Internacional da Lusofonia Afro-Brasileira (UNILAB) - Av. da Abolição, 3, CEP 62.790-000, Redenção, Ceará, Brasil, Fone: (85) 3332-6182. E-mail: rafaelscheffer@unilab.edu.br. https://orcid.org/00000003-2453-3285
} 
agency. Throughout the article, we seek to explore how these transactions should be thought of as a possibility of change within the order, triggered by masters as well as by the enslaved themselves, constituting more complex situations than simple commercial relations.

KEYWORDS: Slavery; Slavetrade; advertisement.

Em 19 de novembro de 1859 o seguinte anúncio foi publicado em um jornal da capital cearense, Fortaleza: "Vende-se um escravo novo, sadio, bom carreiro e serrador de madeiras, só pelo motivo de não querer servir a seu senhor: nesta tipografia se dirá quem o vende" (grifos meus). ${ }^{2}$ No Sul do Império, em 1855, algo semelhante fora observado em Desterro, Santa Catarina: "Vende-se uma escrava sadia, sem vícios, bonita figura, sabendo lavar, engomar e cozinhar, e o mais serviço de uma casa, por ser muito fiel, $o$ motivo da venda é por ela não querer servir; para tratar com o abaixo assignado e para vê-la na Cadeia d'esta Cidade" (grifos meus). ${ }^{3}$ Buscando realizar a venda desses trabalhadores, seus senhores admitiam que a negociação era realizada devido à vontade desses indivíduos, que não mais desejavam serví-los. Anúncios como esses, publicados em periódicos de circulação local em diferentes parte do Império, chamam a atenção para as relações pessoais e não apenas econômicas que se desenvolviam no cotidiano escravista e eram também refletidas no momento da negociação.

As compras e vendas de indivíduos escravizados são tema bastante recorrente na historiografia devido a sua representação como momento de reificação completa desses indivíduos. Contudo, poucos são os estudos que dedicam maior atenção a esses momentos. Em geral, esse comércio é analisado em suas estruturas, organização e dinâmica, sendo percebido como um fenômeno econômico fundamental para a compreensão da história brasileira, americana e africana. Entretanto, existem outras facetas envolvidas nessas

\footnotetext{
${ }^{2}$ Hemeroteca Digital da Biblioteca Nacional Brasileira (HD-BN); Pedro II, n. 1967, de 19 de novembro de 1859. Salvo aviso em contrário, a grafia dos documentos foi atualizada.

${ }^{3}$ Hemeroteca Digital da Biblioteca Nacional Brasileira (HD-BN); O Conservador (SC), n. 350, de 21 de agosto de 1855. Todas as fontes indicadas da Hemeroteca Digital estão disponíveis em http://bndigital.bn.gov.br/hemeroteca-digital/ (e foram consultadas/verificadas em setembro de 2019).
} 
relações que ainda carecem de maior atenção. E são esses aspectos das vendas relacionadas ao trato, agência, disciplina e dinâmica da relação senhor/escravo que pretendo problematizar nesse artigo.

O que proponho debater são as relações sociais que envolviam as vendas, e como elas poderiam não só gerar conflitos, mas também servir como uma resolução para eles. A historiografia já explorou os conflitos relacionados às vendas, com Maria Helena Machado e Sidney Chalhoub, entre outros, apontando como a ameaça da venda para longe era vista como um castigo pelos escravizados, devido a separação das famílias e conhecidos. E como estes trabalhadores tentaram evitar essas transações, fugindo ou enfrentando senhores e negociantes de cativos (MACHADO, 1987 e 2010; CHALHOUB, 1990). Ou ainda negociando e buscando estabelecer limites às opções senhoriais (CHALHOUB, 1990; REIS, 1989), tentando fazer valer seus desejos mesmo na dura condição em que se encontravam, como pode ser visto nos anúncios de venda que abrem este artigo.

Indicações como essas permitem que compreendamos de forma mais complexa o significado desse momento e as expectativas que o cercam, para além da esfera econômica. Pretende-se entender as negociações a partir de seus significados para senhores e cativos, como um momento específico em uma relação de escravização. Se de um lado a venda, em diferentes casos, poderia ser percebida como um instrumento disciplinar imposto pelos senhores, de outro, essa negociação convertia-se numa busca por melhores condições de vida na perspectiva dos escravos, podendo também constituir solução para uma situação insustentável para ambas as partes.

Observada dessa forma, a venda poderia representar não só abalos na ordem escravista, como a crise ou falência de senhores e uma saída para conflitos em torno da disciplina, resultando nas transações como formas de recuperar ou levantar capital. Assim como em punição e quebra de laços familiares e de sociabilidade dos cativos, o que provocava a resistência escrava a isso. A venda poderia representar também uma saída para um conflito que era desejada por uma ou até mesmo ambas as partes. É importante refletirmos que 
para os senhores e os escravos, uma venda poderia significar uma ruptura dentro da ordem que, por si só, não negaria a escravidão, mas permitiria uma nova acomodação.

As fontes principais para a realização da discussão proposta, como já foi indicado, são os anúncios de venda de escravos publicados em jornais brasileiros, em diferentes cidades e províncias (Santa Catarina, São Paulo e Ceará), na segunda metade do século XIX. Esses dados foram recolhidos pelo autor ao longo de diferentes pesquisas nessas localidades. Para o desenvolvimento deste artigo, cabe ressaltar que a própria sistemática de recolhimento dessas fontes foi variada. Os anúncios de compra e venda foram analisados de forma sistemática nos periódicos de Desterro/SC (atual Florianópolis), com a leitura de diversos jornais ${ }^{4}$ e a identificação de 573 anúncios entre 1850 e 1885. Em Campinas, interior de São Paulo, foi realizada a leitura apenas dos periódicos Gazeta de Campinas e Diário de Campinas na década de 1870 e início da seguinte, com uma coleta seletiva de anúncios, mas não fichamento sistemático de todos eles. ${ }^{5}$ Cerca de 47 anúncios foram fichados. Da mesma forma, em Fortaleza/CE, foi realizada a análise de jornais das décadas de 1870 e início de 1880 , fruto de um projeto de pesquisa. Nessa última pesquisa 21 anúncios foram fichados. Apesar das diferentes abordagens e muito embora tenham sido produzidas em regiões tão díspares e afastadas espacialmente, por serem as fontes homogêneas e trazerem aspectos semelhantes da relação senhor/escravo, acredito que os indícios aqui explorados nos possibilitam compreender um fenômeno presente em termos nacionais.

Antes de mais nada, cabe destacar que o uso de anúncios de compra, venda, aluguel ou fuga de escravizados não é uma novidade na historiografia brasileira. Pioneiro na utilização dessa fonte, Gilberto Freyre explorou esses documentos em $O$ escravo nos anúncios de jornais brasileiros do século XIX,

\footnotetext{
${ }^{4}$ Foram analisados os seguintes periódicos: O Novo Íris, Conciliador Catharinense, Correio Catharinense, O Conservador, O Argos, O Mercantil, O Mensageiro, O Cacique, A Província, O Patriota, O Despertador, e A Regeneração.

${ }^{5}$ Nas pesquisas em Campinas e Fortaleza os anúncios foram analisados buscando a participação de comerciantes de escravizados já identificados em outras fontes, sendo registrados como observação também anúncios que traziam uma gama maior de informações ou indicações não usuais.
} 
observando as características físicas, culturais e comportamentais apontadas nos jornais (FREYRE, 1979 - publicado originalmente em 1963). Através dos anúncios de fugas publicados, Freyre buscava explorar o cotidiano, as relações sociais e identitárias dos escravizados, desenvolvendo uma perspectiva que foi revista e ampliada pela historiografia nas décadas mais recentes. Um exemplo da importância dos periódicos para a análise de contexto pode ser vista em Retrato em branco e negro, de Lilia Moritz Schwarcz (SCHWARCZ, 1987), no qual a autora parte dessas fontes para compreender questões do cotidiano e a percepção social sobre a escravidão e seu desenvolvimento nas décadas finais dessa instituição.

Especificamente sobre a fonte em foco, nas últimas décadas diversas pesquisas tem utilizado os anúncios de jornais buscando explorar diferentes aspectos da sociedade escravista (para ficar em estudos que discutiram apenas essa temática). Pesquisas focadas nas fugas de escravos, como as de Flávio dos Santos Gomes (GOMES, 1996), e Martha Rebelatto (REBELATTO, 2006), por exemplo, exploraram os anúncios de escravos fugitivos publicados por seus senhores - que os descreviam buscando a recaptura - analisando as informações para traçar perfis de fugitivos, assim como levantar elementos para compreender suas motivações e estratégias. Em outra iniciativa com os anúncios de fuga, Márcia Amantino (AMANTINO, 2007) analisa as descrições procurando informações sobre a saúde dos escravizados, o que explicita mais uma vez a riqueza de análises tendo como base essas fontes. Seguindo com essa linha de pesquisas, o presente artigo explora os anúncios de venda de escravos publicados em diversos jornais brasileiros entre 1850 e 1880, buscando perceber as diversas tensões, acordos e rupturas que envolviam as negociações de cativos, mas que muitas vezes ficam fora de nossos olhares através de outras fontes (como as escrituras de compra e venda de cativos, muito usadas para a análise desse comércio, por exemplo).

De maneira complementar, foram também trazidas para a discussão notícias de jornais, escrituras de venda de escravos e processos judiciais para problematizar pontos específicos levantados por anúncios de venda. Por fim, é 
importante indicar que a segunda metade do século XIX, aqui em análise, foi um recorte pensado devido à exclusividade do comércio interno de escravos (após o fechamento definitivo do comércio atlântico em 1850), marcada como um momento de intensificação desse trato (cujo contexto, estrutura e motivações gerais são analisados por diversos autores: SLENES, 1976 e 2004; GRAHAM, 2002 e MOTTA, 2012a, SCHEFFER, 2012 E 2016). Além disso, nesse período há uma publicação regular e diversificada de periódicos em praticamente todo o Brasil, o que ajuda a pensar como os problemas levantados na presente discussão foram sentidos ou indicados em diferentes regiões do território nacional. Sem dúvida, as localidades selecionadas trazem contexto diferenciados e distantes, mostrando o tema trabalhado como uma questão que pode ser pensada nacionalmente.

A perspectiva senhorial nos anúncios de venda de escravos

A relação de compra e venda de escravos foi até pouco tempo tratada superficialmente pela historiografia, que entendia esta relação como qualquer outra transação comercial. Nestes estudos, as negociações teriam uma motivação apenas econômica, posição bem demonstrada por Kátia Mattoso ao falar das vendas privadas, ou seja, daquelas que não eram realizadas nos leilões públicos:

Por que essas vendas privadas? Ocorre que um senhor de escravos que tem dificuldades financeiras será obrigado a realizar seu capital para pagar dívidas ou obter dinheiro vivo para suas necessidades cotidianas. Outros desejam vender escravos já idosos, produzindo menos, ou, ao contrário, cedem a uma oferta tentadora feita por um escravo bem dotado (MATTOSO, 2001: 74).

Dessa forma, a necessidade econômica é que ditaria a ocorrência das vendas. Essa visão corrobora a percepção do escravo como um bem "livremente alienável" (GORENDER, 1988: 67), estando centrada na letra fria das leis. Assim, observamos a perspectiva dos senhores nessa negociação, geralmente vista pela historiografia como um momento de desistência do escravismo, de 
necessidade financeira ou busca por melhores oportunidades econômicas, como apontado por Kátia Mattoso e Jacob Gorender.

Essa perspectiva estava relacionada a uma análise mais econômica da escravidão, mas também e diretamente influenciada por uma série de anúncios mais corriqueiros nos jornais, que relacionavam informações bastante simples ao divulgar a intenção de venda de um trabalhador. $O$ anúncio que segue exemplifica um sem número de anúncios que podemos encontrar nos jornais brasileiros, ao longo da segunda metade do século XIX: "Na rua Amelia, casa n. 60, vende-se uma escrava de 26 a 28 anos de idade, faz todo o serviço preciso a casa de que tem família." ${ }^{6}$ Em anúncios como esse, temos informações básicas sobre o perfil do escravo e sua aptidão profissional, além de uma informação para o contato com o vendedor. Nesse caso, a motivação da venda não é apontada, tendo destaque apenas a capacidade da cativa (não nomeada) de realizar "todo o serviço de uma casa" e sua idade aproximada. E apesar desse tipo de descrição ter sido a mais corrente observada nos jornais ao longo da pesquisa, com frequência temos informações complementares, que nos indicam relações mais amplas e problemas na ordem escravista ou na relação de um proprietário com seus trabalhadores.

E essas indicações permitiram que nossa compreensão desses processos se desenvolvesse melhor a partir dos anos 1980, quando diversas questões passaram a ser revistas por estudos que procuraram no cotidiano dos cativos manifestações de resistência e afirmação de sua humanidade e agência histórica. Estudos como os de Robert Slenes, Silvia Lara, João José Reis, Sidney Chalhoub, entre outros, enfatizaram o lado humano dos escravizados no cotidiano, suas experiências, racionalidades e atuação, e revisaram muitas das opiniões correntes à época sobre família, solidariedade, conflitos e resistências na sociedade escravista. Neste ínterim, a própria relação de compra e venda foi revista. A transação passou então a ser vista como uma encruzilhada, como um ponto bastante complexo na relação estabelecida entre senhor e cativo. Por um lado, ainda era uma relação comercial de uma mercadoria (escravo), podendo

\footnotetext{
${ }^{6}$ HD-BN, Pedro II (CE), no 165 , de 09 de Agosto de 1870.
} 
representar, economicamente, o crescimento de determinada região ou senhor, ou sua miséria. Por outro lado, numa análise das pessoas envolvidas, esse momento passou a ser muito mais rico, sendo percebido como um ponto de mudança para a vida dos cativos envolvidos, ponteado por questões políticas (CHALHOUB, 1990: 48).

Através dessa perspectiva, indícios percebidos em certos anúncios passaram a ser inquiridos de forma mais aguda, transformando o modo como vemos as vendas, compreendendo-as também como uma forma dos senhores resolverem problemas com cativos ou situações consideradas difíceis. O anúncio aberto desses problemas nem sempre ocorreu, mas temos indicações bastante claras de algumas dessas situações, como no anúncio que segue: "Vende-se um escravo de nação, de nome Thomaz; é bom padeiro e cozinheiro: quem o pretender dirija-se à rua do Menino Deus n. 22, e para o ver na Cadeia desta Cidade, prefere-se a venda deste escravo para fora da província."7 Além de citar a situação do cativo, que estava preso, o anúncio explicita também problemas com o cativo ao apontar que a própria presença ou manutenção de Thomaz na cidade poderia incomodar ou atormentar o ex-senhor. Isso devido, talvez, ao pequeno tamanho da cidade de Desterro nessa época, e ao temor de futuros encontros e conflitos com este trabalhador. $\mathrm{O}$ fato é que, se em algumas vezes os anúncios não chegavam a apresentar queixas explícitas dos senhores, diversos deles demonstravam o desconforto com a presença dos cativos vendidos na região, caso também do anúncio que segue: "Vende-se para fora da Província, uma escrava crioula de vinte e tantos anos, sem vícios: quem a quizer comprar, dirija-se a esta typographia". ${ }^{8}$

No caso da indicação de que os senhores desejavam a venda de seus trabalhadores para fora da província, pode-se especular que isso se referia a uma busca por melhores preços. Contudo, os negociantes que atuavam nessa atividade poderiam ter sido diretamente procurados pelos senhores, já que eles geralmente anunciavam seus negócios nesses mesmos periódicos. Os anúncios

\footnotetext{
${ }^{7}$ HD-BN, O Novo Íris (SC), n. 171, 14 de novembro de 1851.

${ }^{8}$ HD-BN, O Conservador (SC), n. 191, 24 de janeiro de 1854.
} 
poderiam ter sido colocados para facilitar a aproximação deles e evitar a venda local, mas, de toda forma, reforçam a ideia que a convivência e encontros futuros com os cativos deveriam preferencialmente ser evitados. Nesse aspecto, a venda para fora da província também deve ser pensada como uma forma de "castigo" para o escravizado, como indicamos anteriormente. No fim da década de 1980, Sidney Chalhoub desenvolveu esse debate problematizando as vendas como um momento de tensão nas relações escravistas. Em Visões da Liberdade, o autor discute com detalhes como a imposição de uma venda indesejada se colocava como um problema para muitos escravizados, gerando reações por vezes violentas. Segundo Chalhoub, a separação de familiares e conhecidos desestruturava a vida do cativo, fazendo com que fossem relativamente frequentes as tentativas de evitar, mesmo que à força ou fugindo, a venda para fora da região conhecida (CHALHOUB, 1990: 57-68).

Analisando as transferências de trabalhadores escravizados em Alagoas, Luana Teixeira problematiza a negociação de escravos considerados "belicosos" ou insubmissos por seus senhores. A autora observa que a venda desses trabalhadores no mercado interprovincial servia a um duplo interesse: permitia aos senhores recuperarem o investimento nessa mão de obra (arriscada pela indisciplina do trabalhador) e, ao mesmo tempo, punir esses trabalhadores e dar um exemplo aos demais cativos de sua propriedade (TEIXEIRA, 2016 e 2018). Ao adquirir um cativo, a esperança senhorial era, em geral, de conseguir um trabalhador disciplinado por um longo prazo. Ao ver essa expectativa frustrada, uma possibilidade aberta aos senhores era tentar revender o escravo, recuperar o investimento (ou parte dele) e buscar outra alternativa - inclusive no próprio comércio de cativos. Isabel Reis e Luana Teixeira apontam claramente como essa venda de escravos "insubmissos" era uma forma recorrente dos senhores buscarem "se livrar de um problema" (REIS, 2007: 41) "sem arcar com um considerável prejuízo econômico" (TEIXEIRA, 2018: 134135). Teixeira ainda desenvolve os vários temas que cercam essa opção ao discutir a experiência do escravo Martinho, possibilitando que se percebam as diversas questões, escolhas e conflitos que cercam esse momento. Deixa claro, 
dessa forma, como a venda constitui uma solução não ideal, mas adequada para a resolução de problemas disciplinares, do ponto de vista senhorial.

Apesar disso, em vários momentos observamos nos anúncios os senhores realizarem certa "propaganda negativa" dos seus trabalhadores, como se vê na fonte que segue: "Vende-se uma crioula de treze anos, sabendo cozinhar sofrivelmente; sem vícios e de boa índole. Nesta tipografia se dirá quem vende". 9 Apesar de indicar o bom comportamento da escravizada, o senhor destaca certa falta de habilidade na garota, em um exemplo de informação que parecia estar presente nos anúncios para impedir reclamações futuras dos compradores, ou porque seria algo verificado no ato da compra, através de testes ou conversas com o próprio trabalhador (retornaremos ao contexto do momento da venda posteriormente). Ocultar essa informação poderia resultar em problemas futuros, e em casos mais significativos - como a mentira sobre doenças debilitantes ou um ofício chave para a venda - resultar inclusive em processos de devolução de escravos e nulidade da venda.

A esse respeito, em análise sobre o mercado interno de escravos nos Estados Unidos, Walter Johnson discutiu em detalhes as negociações diretas que envolviam essas vendas. Soul by soul, sua obra mais conhecida, discute o mercado interno buscando compreender a agência dos envolvidos, explorando o lado humano dessas transferências e tendo um impacto significativo na historiografia norte americana sobre a escravidão. Analizando relatos que descrevem os momentos de venda, o autor percebe como os compradores buscavam não apenas vistoriar os trabalhadores colocados à venda, mas também entrevistá-los, verificando informações de especialização profissional, motivação ou disciplina, assim como de pertencimento familiar. Com isso, segundo o autor, compradores de cativos buscavam conhecer o perfil da mão de obra que estavam adquirindo (JOHNSON, 1999: 162-188). Parcialmente, as informações fornecidas nos anúncios dos jornais cumpririam objetivos semelhantes, que poderiam ser conferidas pessoalmente pelos possíveis compradores caso ocorresse interesse na venda.

\footnotetext{
${ }^{9}$ HD-BN, Gazeta de Campinas (SP), no 252, de 28 de Abril de 1872.
} 
Em outra obra de referência sobre o comércio interno nos EUA, Michael Tadman descreve o cotidiano nas lojas de comerciantes de cativos, apontando como esses negociantes buscavam certa cooperação por parte dos escravizados para que sua venda fosse facilitada (TADMAN, 1996: 101). Assim, ao incentivar os escravos para que se mostrassem disciplinados e aptos para o trabalho, para que cooperassem com a vistoria e respondessem as perguntas dos possíveis compradores, os negociantes buscavam facilitar as vendas e ampliar seus lucros, como também aponta Walter Johnson (JOHNSON, 1999: 128-130). Podiam também ameaçar os escravizados, através da separação de famílias ainda unidas ou da venda para senhores considerados severos ou "maus". De uma ou de outra forma, os negociantes pretendiam que os cativos fizessem sua parte em um jogo de construção de expectativas senhoriais, o que nos mostra, em contraste demonstrado por essa preocupação dos negociantes, o espaço de atuação que esses cativos poderiam ter. Cabe salientar que, para além das histórias e da cooperação dos escravizados, ambos os historiadores também perceberam um esforço por parte dos negociantes em melhorar a aparência geral de seus cativos para a venda, através de um melhor tratamento relacionado à alimentação, higiene e descanso, o que reforça a ideia de um certo "teatro" para a realização das vendas, que contava com a atuação dos escravizados (TADMAN, 1996: 98-100; JOHNSON, 1999: 119).

Fosse como fosse, é preciso ter em mente que, caso o comprador se sentisse enganado por uma informação falsa, ele poderia procurar devolver o escravo adquirido. No caso brasileiro, isso também ocorria, como apontado anteriormente, e havia normas legais específicas (Título XVII, do Livro 4 das Ordenações Filipinas) ${ }^{10}$ que permitiam ao comprador "enjeitar" o escravizado adquirido. Com isso ele devolveria o trabalhador e pediria o reembolso do valor pago, caso ficasse comprovada uma moléstia não comunicada ou que o escravizado não possuísse a habilidade propagandeada na venda. Essas situações reforçam a percepção de que o anúncio de limitações, imperícia, ou

\footnotetext{
${ }^{10}$ Ordenações Filipinas, Livro 4, Título XVII. Disponível em: http://www1.ci.uc.pt/ihti/proj/filipinas/14p798.htm; Acesso em: 06 jan. 2020.
} 
mesmo indisciplina dos cativos era parte de um questionamento comum e que seu aviso visava resguardar os vendedores de problemas futuros.

Em paralelo com os estudos norte americanos, as descrições de negociações, entretanto, não são comuns na historiografia brasileira. Nossas próprias fontes parecem ser escassas a esse respeito. Em memórias ou manuais de escravistas, nos quais os senhores procuraram deixar conselhos e informações para seus pares e descendentes sobre os melhores procedimentos de escravistas experientes, não temos uma descrição muito elaborada do momento da venda dos cativos. Na literatura, Aluísio Azevedo descreve em $O$ Mulato uma cena no porto de São Luís do Maranhão, na qual ocorre o exame e negociação de escravizados:

Os corretores de escravos examinavam, à plena luz do sol, os negros e moleques que ali estavam para serem vendidos; revistavam-lhes os dentes, os pés e as virilhas; faziam-lhes perguntas sobre perguntas, batiam-lhes com a biqueira do chapéu nos ombros e nas costas, experimentando-lhes o vigor da musculatura, como se tivessem a comprar cavalos (AZEVEDO, 1996: 16).

$\mathrm{Na}$ descrição de Azevedo, o exame físico e o questionamento dos corretores cumpriam funções semelhantes às observadas nos registros norte americanos, o que nos leva a imaginar que um contexto semelhante se desenrolava aqui. Além disso, e também de forma semelhante ao que descrevem Johnson e Tadman para os EUA, essas conversas poderiam servir de oportunidade para os escravizados atuarem, interferindo assim em seus futuros, tema que será explorado na próxima seção deste artigo.

Retomando à discussão dos anúncios, mais do que a indicação de problemas o que foi bastante comum foi a valorização de características dos cativos apontados, não apenas em relação a suas profissões, mas também quanto ao seu comportamento. "Bom padeiro e cozinheiro", "sem vícios" e "fiel" foram alguns dos comentários que já vimos em anúncios citados anteriormente. A atração de interessados no negócio e a busca por uma venda lucrativa e rápida sem dúvida informaram essa divulgação, que nos mostra também as qualidades desejadas em um cativo sob a perspectiva dos senhores. 
A obediência, disciplina e a capacidade profissional são colocadas como elementos valorizados nessas indicações, explicitando a visão senhorial sobre os trabalhadores desejados e procurados nessas negociações.

Para concluir a discussão sob o ponto de vista senhorial, cabe destacar ainda outro tipo de anúncio de venda, que é a negociação de indivíduos que se encontravam fugidos e foi detectada também através da análise das escrituras de compra de escravos. Em 1850, o seguinte anúncio foi publicado em Desterro:

Fugiu, de João da Costa Pereira, um escravo, crioulo, de nome João, de estatura alta, magro e retinto; terá 34 anos de idade, foi cativo, antes de pertencer ao anunciante, de Domingos Antônio, morador no Biguaçu. Consta ter sido visto nas Picadas, e Pedra Branca, distrito da vila de São José. O anunciante protesta proceder criminalmente contra aquele que o acoutar: quem o apreender será bem gratificado. Também o venderá, mesmo fugido. ${ }^{11}$

A indicação de que a venda de João pode ser realizada "mesmo fugido" chama a atenção, surgindo como um anexo estranho em um anúncio de fuga. Todavia, como poderia ser esperado quando pensamos na lógica de tal publicação (e reconhecendo que há uma racionalidade intrínseca a essa divulgação), encontramos nas escrituras registradas em cartório casos de venda de cativos evadidos. Em 1879, por exemplo, a firma Viúva Barboza Aranha \& Filho comprou de Francisco de Paula Lima o escravo "Antônio, pardo, de 25 anos de idade, solteiro, filiação desconhecida, de qualquer trabalho, com a nota de fugido (...)", por um conto e duzentos mil réis. ${ }^{12}$ Adquirir um escravo fugido representava a compra de um direito sobre o trabalho dele, desde que fosse possível reaver esse trabalhador. $\mathrm{O}$ valor pago por Antônio, que estava abaixo do praticado por um cativo com o seu perfil em Campinas/SP, onde a venda ocorreu, só seria um investimento interessante caso ele pudesse ser encontrado. Podemos especular, nesse ponto, a respeito do nível de risco envolvido no investimento dos compradores. É difícil imaginar que um investimento

\footnotetext{
${ }^{11}$ HD-BN, Concililador Catharinense (SC), n 87, de 06 de Março de 1850.

${ }^{12}$ Escritura de venda de um escravo de nome Antônio, que faz Francisco de Paula Lima por seu procurador, à Viúva Barboza Aranha \& Filho, pela quantia de réis 1:200\$, 07/08/1879. $1^{\circ}$ Tabelionato de notas de Campinas, Cartório Campagnone, Livro de Notas 75, pp. 75v-76.
} 
significativo como esse foi realizado com uma baixa expectativa de retorno ou captura do trabalhador evadido. Assim, a compra pode somente ter ocorrido porque havia informação sobre o paradeiro do cativo, o que permitiria uma possível captura - e um contexto ou ambiente em que as chances dessa captura eram consideradas altas. Ou, ainda mais significativo, poderia haver até um contato ou acordo com o próprio escravizado, que ao encontrar um outro senhor que iria adquirí-lo poderia retornar ao cativeiro diminuindo o risco de um castigo severo (ou seja, realizando esse acordo prévio com o futuro comprador).

Do ponto de vista senhorial, vender um escravizado fugido era uma forma de recuperar parte do investimento realizado - de forma ainda mais clara do que ocorria com cativos indisciplinados. O ponto chave, como apontado anteriormente, é o que faria um comprador adquirir direitos sobre um escravo fugido. Essa expectativa explicita as ações e relações sociais ocorridas fora dos documentos, no contexto das compras (infelizmente não totalmente inteligíveis), que são fundamentais para o entendimento das transações de escravos em sua complexa totalidade. $O$ que nos leva a discutir as possibilidades da ação escrava, percebidas através de elementos indicados nos anúncios. Assim, buscando compreender os interesses dos trabalhadores escravizados nesse processo, dedicamos a próxima seção à perspectiva escrava dessas negociações.

Antes disso, contudo, volto a falar da motivação econômica e gostaria de apontar uma questão que me causa algum incômodo a respeito da abordagem mais tradicional sobre a venda de escravos. O cerne da questão está relacionado à motivação das vendas, pois parece-me ingênuo pensar que os senhores vendiam seus trabalhadores apenas porque o preço estava elevado. O cálculo para essas negociações devia levar em conta não apenas o valor a ser recebido pelos cativos, mas também como era percebida a possibilidade de substituir essa mão de obra. Dessa forma, as vendas de escravos, especialmente para fora de uma região, relacionavam-se com a noção de que havia uma oferta de mão de obra disponível para substituir esses trabalhadores, fossem eles escravos de menor valor, libertos ou trabalhadores livres sob contrato. Além disso, a 
confiança em relações de trabalho livre e no seu funcionamento adequado são também testadas por essa opção, que merecem um debate mais aprofundado que não é a proposta do presente artigo.

\section{A venda como uma possibilidade de melhorar suas condições}

De um outro ponto de partida, podemos perceber que as vendas também foram acionadas por cativos que buscavam melhores condições de vida. Em 1855, um anúncio sumário em Desterro/SC nos indica essa possibilidade: "Na casa $n .1$ da rua do Ouvidor há para vender uma escrava, que pede para ser vendida." 13 O desejo de ser negociada surge aqui declaradamente como uma ação da trabalhadora. Possivelmente, como uma forma de buscar um outro cativeiro, percebido como melhor (ou menos pior), ou aceitável. O mesmo se deu com o escravo Justino, um crioulo de 30 anos, sadio, apto para todo o serviço e também conhecido por Bahia. Em 27 de março de 1874, seu senhor, Clemente Antônio Gonçalves, anunciou sua venda por ele "não querer servir"14. Nos dois casos, não existem maiores informações sobre a motivação dos trabalhadores para se negarem ao serviço de seus atuais proprietários. Entretanto, como não temos a publicização desse motivo, dois pontos parecem ficar claros: a motivação seria uma questão colocada pelo futuro comprador, talvez ao próprio cativo, e por isso não valeria a pena mentir ou fantasiar; e o fato de não querer servir a um senhor não significava, necessariamente, que o cativo negava a sua condição.

Esses dois argumentos se apoiam em diversos exemplos explorados pela historiografia sobre a escravidão no Brasil. Em Campos da Violência, por exemplo, Silvia Lara analisa um processo judicial que remete à discussão do contexto de venda de escravos, das condições e comportamentos a ela associados. Em um caso de 1805, a escrava Maria haveria se mostrado insatisfeita com o seu novo cativeiro e retornado à casa de sua ex-senhora, que

\footnotetext{
${ }^{13}$ HD-BN, O Conservador (SC), n. 373, 16 de novembro de 1855.

${ }^{14}$ Universidade Federal de Santa Catarina/Biblioteca Universitária (UFSC/BU), Setor de Obras Raras. O Despertador (SC), nº 1161, de 27 de março de 1874.
} 
teria (sem consentimento do marido) concedido a liberdade à cativa. Em sua defesa, Maria alegou que jamais fora escrava da autora da causa, D. Ana Maria Francisca. Ela descreve que, quando a autora procurou o seu senhor para adquirí-la, ela foi questionada por uma série de perguntas da pretendente compradora, respondendo à mesma, por fim, que não a queria servir. E, segundo Maria, isso teria posto fim à negociação. A desavença entre os senhores e a postura da escrava devem ter convencido o juiz, que manteve a liberdade de Maria e condenou a autora ao pagamento das custas processuais (LARA, 1988: 160-161). Nesse sentido, Silvia Lara percebe como a "participação do escravo no seu próprio comércio impede que continuemos a analisar a questão da escravidão em termos estritos de "coisificação do escravo" (LARA, 1988: 162). Através da recusa aberta a uma proposta de transferência ou de reações como as fugas, a autora deixa claro como os cativos reagiam a essa situação de venda a partir de seus valores e experiências, o que foi reforçado por pesquisas que se desenvolveram na mesma época e que a sucederam.

Em artigo publicado em 1985, foi com essa perspectiva que Robert Slenes discutiu a petição de D. Francisca Soares de Camargo, registrada em Campinas em 1875. No documento analisado, a senhora pedia autorização para vender o escravo Ignácio, que foi doado condicionalmente à senhora. Segundo ela, o cativo não vinha servindo bem a ela, e ele próprio havia pedido para ser vendido e, inclusive, "já escolheu um senhor de sua vontade (...)" (SLENES, 1985: 176). Em meados da década de 1980, quando o artigo foi publicado, Slenes procurava chamar a atenção para a discussão do cotidiano e das estratégias de luta e agência escrava, em uma historiografia ainda muito marcada por uma perspectiva marxista abalizada pelos debates da estrutura e "modos de produção", por um viés predominantemente econômico. E nesse aspecto, tentar entender como um escravizado poderia não só pedir a sua venda, mas também atuar na escolha de seu próprio senhor era uma intrigante questão que mostrava a agência e possíveis estratégias desses trabalhadores. 
No caso tratado por Silvia Lara, temos a percepção dos senhores de que seria interessante a venda passar pela concordância da própria escrava, mostrando que ela aceitava essa transferência. Isso reforça a ideia, amplamente discutida pela historiografia, da necessidade de certo nível de compreensão e aceitação das regras do cativeiro por parte dos trabalhadores, de cooperação para tornar esse sistema possível. Percebam que esse "certo nível” não deve ser lido como uma relação de iguais, sendo a coerção e a violência uma parte constitutiva e constante dessas relações sociais. A venda poderia ser forçada ao escravo, como os casos de resistência vistos por Chalhoub mostram, mas a referência a esse costume de ouvir o escravizado e sua vontade apontam que o reconhecimento de sua aceitação tornaria a situação menos tensa. Como o próprio Chalhoub demonstra no primeiro capítulo de Visões da Liberdade, os "objetos" das negociações tinham percepções, sentimentos e temores em relação às transferências das quais eram parte. Chalhoub ainda explicita o espaço de manobra que os escravos tinham nessas vendas, das percepções que poderiam passar aos seus futuros compradores e que poderiam ajudar ou arruinar uma venda (CHALHOUB, 1990: 29-80).

Em Crime e escravidão, obra na qual Maria Helena Machado desenvolveu estudos discutindo a agência dos trabalhadores escravizados e sua percepção do contexto a partir de ações criminais que os envolviam (MACHADO, 1987), as referências às situações de venda também estão presentes. É nesse perspectiva que a autora destaca a área de "negociação" entre senhores e cativos:

(...) a quantidade de pão ou pano devidas pelos senhores a seus escravos, quantas horas de descanso semanal e quantas de trabalho, qual a justeza do castigo devido para cada falta particular, foram questões a serem resolvidas, mais ou menos isoladamente, por cada grupo de escravos e seus senhores. Assim, de alguma maneira, cada cativo, individualmente ou com seus parceiros do eito ou das oficinas, encarregava-se de mostrar a seus senhores, feitores e capatazes qual o limite do tolerável e quais as margens de negociação possível na exploração de seu trabalho. Dessa maneira, floresceram no Brasil escravista inúmeros "contratos" entre senhores e escravos, regulamentados não mais que por leis costumeiras ou direitos adquiridos na vida diária, acordos esses 
extremamente variáveis segundo as regiões geográficas, as vicissitudes da produção, mas que, entretanto, parecem ter evoluído ao longo dos séculos, tornando-se, no oitocentos, um caudal crescente de reivindicações escravas (MACHADO, 1987: 58-59).

A "negociação" aparece entre aspas pelo reconhecimento de que era uma relação entre desiguais, não reconhecida pela lei do período (vários temas tratados nesses acordos, como o acumulo de pecúlio, só seriam reconhecidos por lei em 1871). E no contexto e percepções cativas não faltavam as noções sobre a sua comercialização, com os cativos buscando resistir a vendas indesejadas. A autora aponta, inclusive, afirmações de cativos que "preferiam matar alguém e ir pra cadeia do que ser vendido numa fazenda em Campinas..." ou, como o escravizado Guilherme, que dizia que "iria aprontar tal espalhafato que seria invendável” (MACHADO, 1987: 116). Afirmações como essas deixavam claro o reconhecimento de limites e a tentativa de deixá-los claros por parte dos escravizados. E a autora também encontrou referências diretas nos processos crime a respeito do pedido de trabalhadores para que fossem vendidos:

$\mathrm{Ou}$, ainda, daqueles que optavam pela fuga, à procura de quem os comprassem "...por não ter gosto de servir a seu senhor...", alegando, como Jacintho, que "fugiu a 4 anos do poder de seu senhor por maus tratos e que desde então anda procurando outro senhor para comprá-lo mas não tem conseguido por que seu referido senhor pechincha muito (...) (MACHADO, 1987: 116).

Situações e indicações como essas analisadas por Maria Helena Machado revelam uma concepção das regras desse mundo escravista bastante arraigada nos próprios cativos. Pelo que podemos perceber, solicitar a venda surgia como uma forma do escravo romper com um cativeiro seguindo as normas sociais. Ou seja, a propriedade escravista e o direito do senhor estariam preservados por esse pedido, sendo de "bom tom" (se assim podemos considerar) aceitar a vontade do cativo e promover a negociação, o que permitiria a um cativo buscar melhores condições de vivência. Ao não se colocar de acordo com esse pedido (ou dificultar a realização das negociações), 
temos casos de ruptura mais radical da ordem, como a promovida por Jacintho, no caso visto por Machado.

Essa situação - de escravos fugidos buscando compradores - reforça a possibilidade de existência de acordos entre cativos fugidos e senhores que se oferecem para comprá-los, levantada na seção anterior. Com esse tipo de acordo, mantinha-se a aparência de ordem nessa sociedade, ao mesmo tempo em que vendedor, comprador e o próprio trabalhador conseguiriam modificar condições problemáticas. O vendedor resolvia o problema da fuga de seu escravo, o comprador adquiria um trabalhador já havendo - possivelmente combinado uma relação de trabalho e convivência, e o cativo deixava de ser um fugitivo (o que gerava insegurança e a ameaça de punição) e conseguia deixar um cativeiro indesejado. Essa situação também parece estar relacionada ao caso que segue:

\section{$200 \$ 000$ reis}

A quem apreender dois escravos fugidos desde o ano passado próximo. pertencentes a Antônio Luiz Cabral, os quais tinham os sinais seguintes: Domingos, nação Mina, alto, cheio de corpo, cabeça grande, zambo das pernas, metendo os joelhos um pelo outro. Este escravo é perfeito padeiro também se vende. Outro de nome João, alto, fula, e anda dificilmente por ter cravos nas solas dos pés, quem os apreender e entregar a seu senhor receberá a gratificação acima. $^{15}$

$\mathrm{O}$ anúncio de fuga, em uma passagem rápida, torna-se também uma propaganda de um "perfeito padeiro" que seria o africano Domingos. A motivação da fuga permanece desconhecida, mas não podemos descartar a ideia de ter sido uma fuga com o objetivo de negociação, uma categoria apontada por João José Reis e Eduardo Silva, em Negociação e conflito (REIS e SILVA, 1989). Segundo os autores, além de fugas pensadas como definitivas, que visavam romper com a situação escravista, ocorriam também fugas reivindicatórias ou temporárias. Essas serviriam como forma de protesto contra a quebra de acordos, tomada de direitos (costumeiros) ou excessos cometidos pelos senhores. A fuga, assim, poderia se encaixar em uma série de atos

\footnotetext{
${ }^{15}$ HD-BN, Conciliador Catharinense (SC), $\mathrm{n}^{\circ}$ 87, de 06 de Março de 1850.
} 
reivindicatórios, que passariam também pela exposição do desejo da venda, e talvez possam ser (em casos específicos) a consequência de um pedido dessa natureza recusado pelo senhor.

Em um anúncio semelhante ao de Domingos, a motivação da fuga parece ficar um pouco mais clara, como se vê na sequência:

\section{Escrava fugida.}

A Frederico Wagner, morador em Aririú, fugiu, há perto de um mês, uma escrava parda por nome Gertrudes de idade de 26 anos; consta andar pelas bandas da Serraria, talvez em casa de sua primeira senhora. Quem a prender e recolher à cadeia desta capital será generosamente gratificado.

Também se vende a quem fizer conta comprá-la mesmo fugida. Protesta-se contra quem a tiver acoitado.

Desterro 3 de Agosto de $1866 .{ }^{16}$

A parda Gertrudes, segundo informações do senhor que a procurava, poderia estar em casa de sua antiga senhora. Retornar a um lugar conhecido, talvez com familiares e amigos, ou pelo menos uma senhora considerada "melhor" que o atual proprietário poderia ser a motivação desse movimento da cativa. Para evitar perder essa trabalhadora, Frederico Wagner colocou o anúncio e ameaçou as pessoas que pudessem estar escondendo a cativa, indicando claramente ter informações que apontavam que ela havia procurado sua ex-senhora. O que parece claro é o arranjo que ele procura fazer, uma forma de garantir seus direitos pressionando a escrava e a ex-senhora, mas sem necessariamente acionar a Justiça para resolver a questão (o que poderia ocorrer na sequência da situação, caso a ameaça não surtisse efeito).

No caso específico de Jacintho, citado anteriormente e discutido por Machado, a razão do cativeiro inadmissível foram os maus tratos, que podem ser entendidos como castigos excessivos, talvez trabalho em demasia e alimentação precária. Todos esses elementos contribuíram para tornar uma relação senhor/escravo ainda mais indesejável. Mas, além desses motivos, a

\footnotetext{
${ }^{16}$ HD-BH, O Despertador (SC), n ${ }^{\circ}$ 371, de 07 de Agosto de 1866.
} 
pressão escrava sobre as vendas também incidiu sobre os deslocamentos que elas envolviam. Encontramos, em alguns anúncios de venda, a colocação de alguns desejos e limitações ao deslocamento desses trabalhadores, como se observa: "Vende-se uma escrava parda, de 22 a 23 anos de idade, com a condição de não ser para fora da Província, é sadia, e faz todo o serviço; quem a pretender comprar dirija-se a esta tipografia, onde achará com quem tratar." 17

Aqui, a venda para fora da província parece representar a entrada no mercado nacional de cativos e a venda para a lavoura cafeeira no Sudeste, experiência que foi presente na vida de muitos escravizados do Sul do Brasil nesse período. Em outro caso, em que ficou ainda mais explícita a atuação escrava, a cativa Rosa, de 40 anos, foi colocada à venda por sua senhora porque não queria seguir com ela para o Rio Grande do Sul. ${ }^{18}$ Torna-se claro, na situação de Rosa, que é essa trabalhadora que se recusava a seguir com a sua senhora, que buscava, então, contornar a situação através da venda da cativa, o que permitiria que ela e a trabalhadora ficassem mais próximas daquilo que desejavam. A senhora mantinha seu direito de propriedade e buscava conseguir, pela venda, o recurso para outra trabalhadora (talvez uma troca com um escravo disposto a ir para o Rio Grande do Sul, talvez recursos que seriam investidos na compra de outro cativo ou contratação de um trabalhador livre no seu destino). Ela evitava, além disso, o risco de uma fuga ou reação da cativa. Por sua vez, Rosa se manteria na região, em um contexto de trabalho conhecido e próxima de familiares e amigos.

E esse desejo dos trabalhadores escravizados de permanecerem em regiões conhecidas e próximos de uma rede de apoio foi percebido por diversos estudos recentes. Analisando os impactos e a organização do comércio interno no Ceará, província que foi grande exportadora de escravos no mercado nacional, José Hilário Ferreira Sobrinho explora as resistências, troca de informação e estratégias dos escravizados para evitar serem tragados por essas transferências, buscando preservar suas famílias e relações de sociabilidade

\footnotetext{
${ }^{17}$ HD-BN, O Correio Catharinense (SC), $\mathrm{n}^{\mathrm{o}}$ 58, de 21 de Dezembro de 1853.

${ }^{18}$ UFSC/BU. O Despertador (SC), n ${ }^{\circ}$ 527, de 07 de Fevereiro de 1868.
} 
(FERREIRA SOBRINHO, 2011). Percebendo as condições de trabalho no Sudeste e a separação das famílias e conhecidos como uma ameaça real, escravos buscaram recursos para se manterem em suas regiões, negociando com os senhores, usando a lei para impedir a separação de suas famílias ou mesmo entrando com pedidos de alforria (acionando familiares e conhecidos para conseguir os recursos adequados), como aponta Joice Oliveira (OLIVEIRA, 2019; OLIVEIRA e SCHEFFER, 2019). Lidando com as consequências dessas transferências, Oliveira também analisa como escravizados transferidos pelo comércio interno de cativos buscaram se reorganizar e agir visando manter ou reconstituir suas relações sociais e familiares, entendendo como as diferentes experiências de comercialização afetavam a comunidade escrava e negra (OLIVEIRA, 2013).

No caso específico do uso da lei para impedir as vendas e separação de famílias, cabe ressaltar o artigo de José Flávio Motta. Além de analisar o comércio interno de escravos relacionada à expansão cafeeira no Sudeste, Motta estuda não só a presença de diferentes grupos - crianças e idosos - entre os escravos negociados, mas também os esforços e estratégias de vendedores e compradores para burlar a legislação que limitava as vendas (MOTTA, 2010, 2012a, 2012b e 2015). Com essa análise o autor deixa claro como a lei e seu uso, mais do que estabelecer um campo de possibilidade, formava também um campo de conflito entre os interesses em jogo, indicando mais uma vez as complexas relações sociais presentes nessas transferências.

Retomando à questão do comércio interno de escravos, como reflexo da ampliação dessas transferências observamos nos anúncios a indicação de que a compra não estava sendo feita "para negócio". Em um contexto da década de 1870 no qual a mão de obra escrava estava sendo adquirida em Desterro para revenda no Sudeste, encontramos uma série de anúncios como os que seguem: "Compra-se dois escravos crioulos, de idade de 14 a 40 anos, para o serviço de uma chácara, e não para negócio, sendo sadios e sem imperfeição física. Trata- 
se com Domingos L. do Livramento". ${ }^{19}$ A indicação de que não seriam para negócio, ou seja, comercialização, aponta uma recusa que pode partir tanto dos senhores, baseada em uma moral patriarcal usada no discurso senhorial, quanto de uma inquietação e pressão dos escravizados, o que acho mais significativo e presente em todos os processos (independente da vontade ou visão dos proprietários).

A esse tipo de indicação se junta uma outra, também bastante usual: "Compra-se escravos de 15 a 30 anos de idade, para ficarem dentro da cidade; para informações na padaria da Praça, n. 9",20 ou "Precisa-se comprar duas escravas moças e sadias, preferindo-se que uma seja regulando de 10 a 11 anos de idade. Garante-se serem para serviço doméstico de uma família residente nesta cidade. Trata-se com o abaixo assinado. Desterro, 16 de Março de 1880, Severo Francisco Pereira". ${ }^{21}$ O anúncio de que as trabalhadoras não estavam sendo adquiridos para o comércio interno ou revenda, e que permaneceriam em serviço na cidade de Desterro (cidade de todo estes exemplos) demonstra as desejadas limitações colocadas às transferências. Essa era uma condição que os vendedores (e os próprios escravizados) poderiam checar em uma conversa pessoal na negociação, mas o fato dessa postura ser explicitada nos anúncios parece mostrar a força que esse posicionamento possuía.

O desejo de manter os laços familiares e as relações estabelecidas na região, motivação presumível da pressão dos escravos para ficarem em uma área conhecida, junta-se à resistência aberta contra as vendas indesejadas observada por Chalhoub e outros pesquisadores, como vimos anteriormente. A percepção dessas ações como parte de um único movimento é o que torna compreensíveis ações como a da senhora de Rosa - escrava que não desejava acompanhar sua senhora para o Rio Grande do Sul. Entender os desejos e certos limites expostos pelos cativos significava, para os senhores, evitar quebras de disciplina e revoltas, construindo e mantendo um domínio sobre seus cativos

${ }^{19}$ HD-BN, O Conservador: Jornal Político, Noticioso e Comercial (SC), $\mathrm{n}^{\mathbf{o}} 379,18$ de Novembro de 1876.

${ }^{20}$ HD-BN, O Despertador (SC), $\mathrm{n}^{\circ}$ 1002, de 07 de Setembro de 1872.

${ }^{21}$ HD-BN, A Regeneração (SC), nº 22, de 21 de Março de 1880. 
que não era absoluto, mas o possível estabelecido em uma relação hierárquica entre dois indivíduos. Ao anunciar a vontade da escrava em um anúncio de venda, ela explicitava, do meu ponto de vista, o entendimento de que é necessário contar com certa concordância do cativo em seu cativeiro, com a aceitação das regras que lhe são impostas.

Fora do desejo escravo de permanecer na região, não vejo nos senhores outra motivação para limitar as vendas à localidade. Por mais que eles pudessem recriminar a ação de comerciantes de escravos, por vezes criticados por políticos e a imprensa da região, a ingerência sobre o destino de seus exescravos era somente um desejo, e não algo que tivesse um valor legal. Dessa forma, indicar a um futuro comprador que o escravo não deveria sair da província ou da região me parece o reflexo de um acordo estabelecido entre senhor e escravo, explicitado no anúncio de venda para tornar claro ao futuro comprador esse trato (o que poderia ser reforçado nas conversas e tratativas que antecediam a venda de fato).

Outros anúncios apresentam motivações de venda mais difusa e de difícil compreensão, como o que abaixo se segue, e que ocorreu ainda no ano de 1849:

No campo do manejo, casa pintada de novo, vende-se um bonito crioulinho de 10 anos de idade, sem achaque e hábil, reforçado de corpo, próprio para pajem ou qualquer ofício; não se constrange ao comprador pelo dinheiro; e sim pela segurança do mesmo; dizendo-se o motivo da venda; dirigirse ao Sr. Tenente do $6^{\circ}$ Batalhão Araújo, ou a sua Sra. ${ }^{22}$

$\mathrm{O}$ anunciante, neste caso, faz uma referência confusa à motivação da venda, dando a entender que a segurança e não o dinheiro seria o que o levou à negociação. Não fica claro, mas parece que se trata da segurança do jovem trabalhador, o que nos leva a pensar na causa desse risco. Infelizmente não temos informações complementares, mas ao mostrar essa preocupação com o escravo temos, mais uma vez, uma demonstração de como a situação dos cativos poderia ser considerada importante para o contexto da venda.

\footnotetext{
${ }^{22}$ HD-BN, Conciliador Catharinense (SC), $\mathrm{n}^{\circ} 38$, de 15 de Setembro de 1849.
} 


\section{Considerações Finais}

As análises dedicadas ao comércio interno de escravos no Brasil, em conexão com os avanços na história social da escravidão, tem trazido ao debate uma série de considerações significativas sobre como essas negociações faziam parte de um contexto e de relações sociais complexas. Dos trabalhos de Robert Slenes que procuraram entender a estrutura desse mercado e suas conexões com os diversos contextos escravistas brasileiros (SLENES, 1976 e 2004), o desenvolvimento das discussões tem se encaminhado nos trabalhos mais recentes que procuram entender o impacto dessas transferências em localidades específicas. Os impactos dessas transferências são comparados aos do tráfico atlântico por Richard Graham (GRAHAM, 2002), que realiza uma leitura ampla desse movimento, assim como o artigo mais recente de Slenes que revisita essa discussão e reposiciona esse debate (SLENES, 2004) com as discussões mais atuais.

Recentemente, uma série de pesquisas mais específicas sobre o comércio interno e/ou seus impactos na população escrava no Brasil vem trazendo contribuições importantíssimas para compreendermos melhor essas transações, escolhas e impactos sociais que elas envolveram. Erivaldo Neves (NEVES, 2000), Mariana Flausino (FLAUSINO, 2006), Maria de Fátima Novaes Pires (PIRES, 2009), José Flávio Motta, José Hilário Ferreira Sobrinho, Luana Teixeira, José Maia Bezerra Neto, Luiz Carlos Laurindo Junior (BEZERRA NETO e LAURINDO JUNIOR, 2018) e Joice Oliveira vêm ampliando nossa percepção das relações sociais afetadas pelo comércio interno de escravos em diferentes contextos. Além disso, alguns desses estudos procuram explorar as perspectivas dos escravizados envolvidos ou ameaçados por essas transferências, discutindo a agência e a experiência dos escravizados que se desenvolvem nessas lutas.

Tomadas em conjunto, o que as discussões de uma série de historiadores nos colocam é que, da mesma forma como a própria escravidão era uma instituição mais complexa do que as normas legais que a regiam, construindo-se 
muitas vezes por regras costumeiras não escritas que concediam certa autonomia aos cativos, a relação de compra e venda também pode ser colocada nessa perspectiva. Assim, o presente artigo visou contibuir com esse debate analisando o momento da negociação - seus conflitos, tensões e estratégias subjacentes - através dos anúncios de compra e venda de cativos, nos quais percebemos uma série de indícios que explicitam como o momento da venda se relacionava com situações do cotidiano senhor/escravo.

A análise dos anúncios indica, mesmo que pontualmente, a complexidade dos interesses no contexto de venda de um escravizado, o que reforça a crítica a uma visão puramente econômica dessas relações. Os limites expostos nas ofertas publicadas apontam para a percepção da vontade escrava, e do estabelecimento da demarcação das situações consideradas aceitáveis. Mesmo em uma conjuntura de inferiorização na sociedade, mulheres e homens buscaram demonstrar seus anseios e limitar a dominação senhorial. Calculando o risco potencial de desafiá-los abertamente, encontramos senhores que procuraram o mercado de escravos como uma forma de romper relações problemáticas dentro da ordem escravista. Ao expor suas insatisfações de forma mais ou menos radical, por sua vez, os trabalhadores buscavam senhores dispostos a ouvi-los e fugir de conflitos futuros. A divulgação da venda de escravos "que não queriam servir" a seus senhores parece indicar de forma direta que o que estava em jogo não era, necessariamente, a negação do cativeiro, mas sim de condições específicas vivenciadas dentro dele. Assim, além dos potenciais conflitos e tensões criados em torno das vendas, foi percebido ao longo deste artigo que esses momentos podem e devem ser vistos também como soluções desejadas por uma ou ambas as partes envolvidas, como uma válvula de escape para as tensões acumuladas no cotidiano.

\section{Referências}

AMANTINO, Márcia. As condições físicas e de saúde dos escravos fugitivos anunciados no Jornal do Commercio (RJ) em 1850. História, Ciências, SaúdeManguinhos, Rio de Janeiro, vol.14, no.4, p. 1377-1399, Oct./Dec. 2007. 
AZEVEDO, Aluísio. O mulato. 13ª ed, São Paulo: Ática, 1996. 247 p. Essa obra foi originalmente publicada em 1881 .

BEZERRA NETO, José Maia; LAURINDO JUNIOR, Luiz Carlos. Alguns vêm de lá, outros de cá: a Amazônia no tráfico interno brasileiro de escravos (século XIX). História, São Paulo, v. 37, 2018.

CHALHOUB, Sidney. Visões da liberdade: uma história das últimas décadas da escravidão na corte. São Paulo: Companhia das Letras, 1990, 287 p.

FERREIRA SOBRINHO, José Hilário. "Catirina, minha nêga, tão querendo te vende...": escravidão, tráfico e negócios no Ceará do século XIX (18501888). Fortaleza: SECULT/CE, 2011, 332 p.

FLAUSINO, Camila Carolina. Negócios da Escravidão: tráfico interno de escravos em Mariana, 1850-1888. 2006. 202 f. Dissertação (Mestrado em História) - Instituto de Ciências Humanas, Universidade Federal de Juiz de Fora, Juiz de Fora, 2006.

FREYRE, Gilberto. O escravo nos anúncios de jornais brasileiros do século XIX. $2^{\text {a }}$ ed. aum. São Paulo/Recife: Nacional/Instituto Joaquim Nabuco de Pesquisas Sociais, 1979, 125 p.

GOMES, Flávio dos Santos. Jogando a rede, revendo as malhas: fugas e fugitivos no Brasil. Revista Tempo, Rio de Janeiro, n. 1, p. 67-93, 1996.

GORENDER, Jacob. O escravismo colonial. $5^{\text {a }}$ ed. São Paulo: Ática, 1988. $632 \mathrm{p}$.

GRAHAM, Richard. Nos tumbeiros mais uma vez? O comércio interprovincial de escravos no Brasil. Afro-Ásia, Salvador, n. 27, p. 121-160, 2002.

LARA, Silvia. Campos da violência: escravos e senhores na capitania do Rio de Janeiro, 1750-1808. Rio de Janeiro: Paz e Terra, 1988, 389 p.

JOHNSON, Walter. Soul by soul: life inside the antebellum slave market. Harvard University Press: Cambridge, 1999, 283 p.

MACHADO, Maria Helena. Crime e escravidão: trabalho, luta e resistência nas lavouras paulistas 1830-1888. São Paulo: Brasiliense, 1987, 134 p.

MACHADO, Maria Helena Pereira Toledo. O plano e o pânico: os movimentos sociais na década da abolição. $2^{a}$ ed. rev. São Paulo: Edusp, 2010, $248 \mathrm{p}$. 
MATTOSO, Kátia M. de Queirós. Ser escravo no Brasil. $3^{\text {a }}$ ed. São Paulo: Brasiliense, 2001, 267 p.

MOTTA, José Flávio. O tráfico de escravos velhos (província de São Paulo, 1861-1887). História: Questões \& Debates, Curitiba, n. 52, p. 41-73, jan./jun. 2010. Disponível em: https://revistas.ufpr.br/historia/article/view/24109. Acesso em 20 jun. 2019.

MOTTA, José Flavio. Escravos daqui, dali e de mais além: o tráfico interno de cativos na expansão cafeeira paulista (Areias, Guaratinguetá, Constituição/Piracicaba e Casa Branca, 1961-1887). São Paulo: Alameda, 2012a, 392 p.

MOTTA, José Flávio. A lei, ora a lei! driblando a legislação no tráfico interno de escravos no Brasil (1861-1887). História e economia: revista interdisciplinar, São Paulo, v. 10, n. 1, p. 15-28, 2012 b.

MOTTA, José Flávio. Crianças no apogeu do tráfico interno de escravos (Piracicaba, província de São Paulo, 1874-1880). História econômica \& história de empresas, v. 18, n. 2, p. 291-322, 2015.

NEVES, Erivaldo Fagundes. "Sampauleiros traficantes: comércio de escravos do alto sertão da Bahia para o Oeste cafeeiro paulista". Afro-Ásia, Salvador, n. 24, p. 97-128, 2000.

OLIVEIRA, Joice Fernanda de Souza Oliveira. Forasteiros no oeste paulista: escravos no comércio interno de cativos e suas experiências em Campinas, 1850-1888. 2013. 197 f. Dissertação (Mestrado em História Social) - Instituto de Filosofia e Ciências Humanas, Universidade Estadual de Campinas. Campinas, 2013.

OLIVEIRA, Joice Fernanda de Souza Oliveira. Atando e desatando nós: negociantes e cativos no comércio interno de escravizados, 1850-1888. 2019. 270 f. Tese (Doutorado em História Social) - Instituto de Filosofia e Ciências Humanas, Universidade Estadual de Campinas. Campinas, 2019.

OLIVEIRA, Joice Fernanda de Souza Oliveira; SCHEFFER, Rafael da Cunha. Lares partidos: o impacto do comércio interno de escravizados sobre as famílias cativas e negras, Salvador/BA e Campinas/SP, 1820-1881. Rev. Hist. (São Paulo), São Paulo, n. 178, 2019.

PIRES, Maria de Fátima Novaes. Fio da Vida: Tráfico interprovincial e alforrias nos Sertoins de Sima- BA (1860-1920). São Paulo: Annablume, 2009, $307 \mathrm{p}$.

REBELATTO, Martha. Fugas e quilombos na Ilha de Santa Catarina, século XIX. 2006. 160 f. Dissertação (Mestrado em História) - Centro de Filosofia e 
Ciências Humanas, Universidade Federal de Santa Catarina. Florianópolis, 2006.

REIS, Isabel Cristina Ferreira dos. Família negra no tempo da escravidão: Bahia, 1850-1888. 2007. 300 f. Tese (Doutorado em História) - Instituto de Filosofia e Ciências Humanas, Universidade Estadual de Campinas. Campinas, 2007.

REIS, João José; SILVA, Eduardo. Negociação e conflito: a resistência negra no Brasil escravista. São Paulo: Companhia das Letras, 1989, 151 p.

SCHEFFER, Rafael da Cunha. Tráfico interprovincial e comerciantes de escravos em Desterro, 1849-1888. 2006. 171 f. Dissertação (Mestrado em História) - Centro de Filosofia e Ciências Humanas, Universidade Federal de Santa Catarina. Florianópolis, 2006.

SCHEFFER, Rafael da Cunha. Comércio de escravos do Sul para o Sudeste, 1850-1888: economias microregionais, redes de negociantes e experiência cativa. 2012. 342 f. Tese (Doutorado em História Social) - Instituto de Filosofia e Ciências Humanas, Universidade Estadual de Campinas. Campinas, 2012

SCHEFFER, Rafael da Cunha. "Redes de comércio interno de cativos: organização dos negociantes na segunda metade do século XIX". AfroAsia, Salvador, n. 54, pp. 151-187, 2016.

SCHWARCZ, Lilia Moritz. Retrato em branco e negro: jornais, escravos e cidadãos em São Paulo no final do século XIX. São Paulo: Companhia das Letras, 1987, $284 \mathrm{p}$.

SLENES, Robert W. The demography and economics of Brazilian slavery: 1850-1888. 1976. 749 f. Tese (Doutorado em História) - Stanford University. Palo Alto, 1976.

SLENES, Robert. Escravos, cartórios e desburocratização: o que Rui Barbosa não queimou será destruído agora? Revista Brasileira de História, São Paulo, v. $5, \mathrm{n}^{\mathrm{o}} 10, \mathrm{pp}$ 166-196, mar./ago 1985. Disponível em: http://www.anpuh.org/revistabrasileira/view?ID_REVISTA_BRASILEIRA=31 . Acesso em: 20 mar. 2017.

SLENES, Robert W. The Brazilian internal slave trade, 1850-1888: Regional economies, slave experience and the politics of a peculiar market. In: JOHNSON, Walter (ed.). The Chattel Principle: internal slave trade in the Americas. New Haven: Yale University Press, 2004, 389 p.

TADMAN, Michael. Speculators and slaves: masters, traders, and slaves in the Old South. Winsconsin University Press, 1996, 356 p. 
TEIXEIRA, Luana. Comércio interprovincial de escravos em Alagoas no Segundo Reinado. 2016. 309 f. Tese (Doutorado em História) - Centro de Filosofia e Ciências Humanas, Universidade Federal de Pernambuco. Recife, 2016.

TEIXEIRA, Luana. "Atrevidos e belicosos": cativos insubmissos no comércio interprovincial de escravos. Revista Brasileira de História, São Paulo, v. 38, $\mathrm{n}^{\circ} \quad 79, \quad$ p. 131-149, 2018. Disponível em: http://www.scielo.br/scielo.php?script=sci_arttext\&pid=S0102-

$\underline{01882018000300008 \& \operatorname{lng}=e n \& n r m=i s o \& t \operatorname{lng}=p t}$. Acesso em: 15 set. 2019.

Recebido em: 06 de agosto de 2020

Aceito em: 24 de agosto de 2021 